\title{
Surgical Management of Renal Cell Carcinoma
}

\author{
Laura-Maria Krabbe, MD ${ }^{1,2}$ Aditya Bagrodia, MD $\quad$ Vitaly Margulis, MD 2 Christopher G. Wood, MD, FACS 3 \\ ${ }^{1}$ Department of Urology, the University of Muenster Medical Center, \\ Muenster, Germany \\ 2 Department of Urology, UT Southwestern Medical Center, \\ Dallas, Texas \\ Address for correspondence Christopher G. Wood, MD, FACS, \\ Department of Urology, MD Anderson Cancer Center, 1515 Holcombe- \\ Unit 1373, Houston, TX 77030 (e-mail: cgwood@mdanderson.org).
}

${ }^{3}$ Department of Urology, MD Anderson Cancer Center, Houston, Texas

Semin Intervent Radiol 2014;31:27-32

\begin{abstract}
Keywords

- renal cell carcinoma

- surgical management

- radical nephrectomy

- nephron-sparing surgery

Surgical resection of renal cell carcinoma (RCC) is the benchmark for long-term cure of the disease. Although open or laparoscopic radical nephrectomy is considered the gold standard for stage T1b-T4 tumors, nephron-sparing surgery is the preferred operative modality for small renal masses demonstrating equivalent oncologic efficacy and improved renal function outcomes compared with complete nephrectomy. With the advance of minimally invasive surgery, nephron-sparing procedures can safely be conducted laparoscopically with or without robotic assistance. RCC with intravenous tumor thrombus presents a surgical challenge, but multidisciplinary surgical approaches can provide long-term benefit in these patients. The role of cytoreductive nephrectomy and metastasectomy in patients with metastatic RCC (mRCC) is controversial, but seems to be beneficial for patients in the era of targeted therapy.
\end{abstract}

Objectives: Upon completion of this article, the reader will be able to describe the current surgical management of renal cell carcinoma.

Accreditation: This activity has been planned and implemented in accordance with the Essential Areas and Policies of the Accreditation Council for Continuing Medical Education (ACCME) through the joint sponsorship of Tufts University School of Medicine (TUSM) and Thieme Medical Publishers, New York. TUSM is accredited by the ACCME to provide continuing medical education for physicians.

Credit: Tufts University School of Medicine designates this journal-based CME activity for a maximum of 1 AMA PRA Category 1 Credit $^{\mathrm{TM}}$. Physicians should claim only the credit commensurate with the extent of their participation in the activity.

Renal cell carcinoma (RCC) is estimated to be responsible for more than $90 \%$ of 65,150 newly diagnosed kidney cancer cases and 13,680 cancer deaths in $2013 .{ }^{1}$ Due to increased utilization and availability of computed tomography (CT) and magnetic resonance imaging (MRI), more renal masses are being identified and a concomitant stage migration has occurred, such that renal masses are being identified at much earlier stages before symptoms suggest advanced disease. ${ }^{2,3}$ Incidentally discovered renal masses currently comprise 48 to $66 \%$ of tumors, compared with only 3 to $13 \%$ in the 1970 s. $^{4}$ Nevertheless, approximately 20 to $30 \%$ of patients have metastases at initial presentation. Even after surgical resection for clinically localized disease, 20 to $40 \%$ of patients will relapse and have a poor prognosis with respect to long-term survival. ${ }^{5,6}$ Even with the new targeted systemic therapies being developed and approved in the last decade, rarely do they provide complete or long-term responses. The only possibility of long-term cure and survival of RCC involve surgical interventions including radical nephrectomy, partial nephrectomy (PN), ablative techniques, and, in selected cases, metastasectomy in combination with multimodal treatment approaches. ${ }^{7}$ This article will review the current surgical management of RCC for clinically localized, locally advanced, and metastatic conditions.

\section{Radical Nephrectomy}

Since first described by Robson et al in 1969, open radical nephrectomy (ORN) has been the gold standard of treating malignant renal masses with a curative intention for decades. ${ }^{8}$
Issue Theme Renal Malignancies; Guest Editors, Bradley B. Pua, MD and David C. Madoff, MD, FSIR
Copyright (c) 2014 by Thieme Medical Publishers, Inc., 333 Seventh Avenue, New York, NY 10001, USA. Tel: +1(212) 584-4662.
DOI http://dx.doi.org/ 10.1055/s-0033-1363840. ISSN 0739-9529. 
In contrast to previously described pericapsular nephrectomy, radical nephrectomy included the en bloc resection of the entire kidney as well as the surrounding perinephric fat, the ipsilateral adrenal gland, and the regional lymph nodes. ${ }^{8}$ This improved overall survival (OS) significantly at that time to around $65 \%$ for localized RCC. ${ }^{8}$ Surgical access to the kidney can be achieved through several means, including a retroperitoneal approach with a flank incision, transperitoneal access by a midline or subcostal incision, or in case of large, upper pole tumors by a thoracoabdominal approach.

With technical advantages of cross-sectional imaging and the widespread use of CT and MRI, the detection of incidental small tumors has increased significantly and changed the surgical approach to RCC. $^{9}$ Minimally invasive techniques have been developed and nephron-sparing surgery (NSS) has been added to the possible treatments. ${ }^{10,11}$ These innovations, critical discussion about conventional ORN arose, and the benefit of routine removal of the adrenal gland and regional or extended lymphadenectomy was questioned.

Several studies demonstrated the low incidence of adrenal metastasis in final pathologic ORN specimens, with detection rates around 4 to $6 \%$ primarily in upper pole tumors or with advanced $\mathrm{T}$ stages $(40,7.8$, and $0.6 \%$ probability of adrenal spread in T4, T3, and T1-2 tumors, respectively). ${ }^{12-14}$ Also high sensitivity and specificity of presurgical imaging was confirmed, so that routine removal of the adrenal gland is not recommended any longer for low-stage tumors without any sign of adrenal involvement clinically or by cross-sectional imaging. ${ }^{14}$

The role and extent of regional lymphadenectomy is yet to be elucidated, even though lymphadenectomy provides the most accurate method of staging and detecting lymph node metastasis. If not clinically and radiographically suspected, incidence of lymph node involvement is as low as 4 to $14 \%$. Further, lymphadenectomy does not consistently improve overall or cancer-specific survival in localized RCC (T1-2). ${ }^{15,16}$ Since the risk of lymph node involvement increases with increasing T stage $(1.1,4.5$, and $12.3 \%$ for $\mathrm{T} 1, \mathrm{~T} 2$, and $\mathrm{T} 3$, respectively), mostly patients with locally advanced stages (T3-T4) profit from regional or even extended lymph node dissection (resulting in longer disease-specific survival). ${ }^{17,18}$ The anatomy of renal lymphatic drainage is quite variable. Only $7 \%$ of patients drain primarily in the ipsilateral hilar area while more commonly the para-aortic nodes are the drainage sites (approximately 27\%), which makes lymphadenectomy approaches difficult to standardize. ${ }^{19}$

In the $1990 \mathrm{~s}$, minimally invasive approaches to radical nephrectomy were developed, and subsequently laparoscopic radical nephrectomy (LRN) has become a widely adopted procedure. ${ }^{20}$ LRN be performed by transperitoneal, retroperitoneal, and hand-assisted approaches. Due to equivalent oncologic control with lower morbidity, improved complication profile, and faster convalescence than ORN, LRN is now considered standard in a patient population not amenable to NSS and with tumor stages up to T1-3, N0, M0. ${ }^{21-24}$ Multiple studies demonstrated improved perioperative and postoperative outcomes such as decreased blood loss, decreased operative time, shorter hospital stay, less need for analgesia, and faster recovery to normal physical activity. ${ }^{25,26}$

Radical nephrectomy approaches (ORN and LRN) have been shown to be associated with the development of chronic kidney disease (CKD) and related morbidity, such as necessity of hemodialysis, cardiovascular disease, and cardiovascularrelated mortality. ${ }^{27-29}$ It is for this reason that is why ORN and LRN have been questioned as the procedure of choice for small renal tumors otherwise amenable to nephron-sparing approaches, such as $\mathrm{PN} .^{30,31}$

\section{Partial Nephrectomy}

After initial descriptions in the 19th century, PN or NSS was rarely used until approximately two decades ago; this was due largely to the high morbidity and mortality linked to these procedures at that time. The basic principle of PN is to excise the tumor with a rim of normal renal parenchyma, usually using temporary occlusion of the vascular pedicle, closure of any open collecting system and vessels, and finally capsular reconstruction. Initially, PN was reserved for patients with imperative indications, including anatomical or functional solitary kidney, bilateral tumors, predisposing syndromes such as von Hippel Lindau disease, and patients with CKD or general predispositions to CKD such as diabetes, renal artery stenosis, and nephrosclerosis, to prevent anephricity or high risk for dialysis. ${ }^{32}$ With improvements in radiological imaging, surgical technique, knowledge about ischemic effects on the kidney, and downstream effects of CKD after RN, PN has resurfaced as an attractive alternative to RN (see - Fig. 1). PN has been adopted as standard procedure for small renal masses even in patients without an imperative indication, due to the benefit of preserving renal parenchyma and thus renal function with equivalent oncological outcomes. ${ }^{30,33}$ Various studies have demonstrated equal oncologic outcomes (5-year disease-specific survival up to 96\%) for patients with T1a (up to $4 \mathrm{~cm}$ ) tumors treated with PN compared with patients treated with $\mathrm{RN} .^{33,34} \mathrm{~A}$ recent population-based analysis comparing outcomes for PN and RN for T1a tumors indicates that a virtually perfect disease-specific survival rate ( $97.5 \%$ or better) was achieved by $\mathrm{PN} .{ }^{35}$ There is evidence the same appears to be true for select T1b $(4-7 \mathrm{~cm})$ tumors in terms of oncologic outcome (5-year disease-specific survival rate of $98 \%$ ), with superiority of PN as for preventing CKD and preserving renal function, thereby preventing secondary causes of morbidity and mortality such as cardiovascular disease. ${ }^{27,36,37}$ In highly selected patients, PN seems oncologically effective and safe even in patients with higher tumor stages (T2 [>7 cm but confined to kidney]; T3a/b [spreading to perinephric fat/renal vein or infradiaphragmatic inferior vena cava, IVC]). ${ }^{38}$ There remains some debate regarding the unequivocal benefit of NSS for small renal masses, primarily because a randomized, prospective trial failed to demonstrate a clear benefit to PN compared with RN. However, this study had significant limitations that led the authors to interpret the results with caution. ${ }^{31}$

The role of margin width, its implication for prognosis, and the concern for local recurrence of RCC after PN are also 

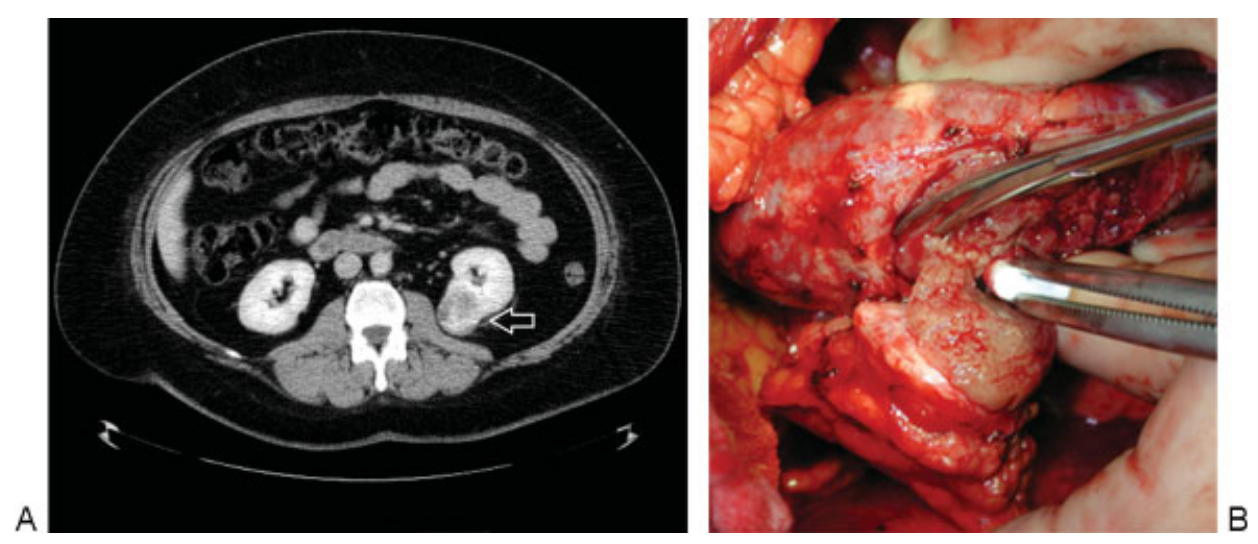

Figure 1 (A) Radiologic image and (B) intraoperative view of a left renal tumor amenable to partial nephrectomy (arrow, A).

debated. Margin width seems to have no effect on oncologic outcome and survival when the final margin is negative, and the risk of recurrence seems to be negligible even when margins are slightly positive. ${ }^{39-41}$ Fortunately, local recurrences after PN are rare and range between 0 and $10 \%$ overall, and data demonstrate even lower recurrence rates for $\mathrm{T} 1 \mathrm{a}$ tumors $(0-3 \%)$ in patients undergoing elective PN. ${ }^{30}$ In addition to the oncologic equivalence between $\mathrm{RN}$ and $\mathrm{PN}$, patients after PN have a better quality of life compared with patients who undergo RN. ${ }^{42}$

Vascular clamping during PN is frequently used to improve hemostasis and visibility during the procedure to enable precise closure of the collecting system, vascular structures, and the parenchymal defect. Ischemia time during PN and the percentage of kidney preserved have a tremendous effect on renal function of the remnant kidney after surgery. The surgery can be performed with warm, cold, and no ischemia. Warm ischemia time should not exceed 20 to 25 minutes to prevent renal damage and progression to severe CKD. ${ }^{43}$ If PN does not seem feasible with a warm ischemia time around 20 minutes, cold ischemia should be used. Cutoff times to avoid impairment of renal function are not clearly defined but should not exceed 35 minutes. ${ }^{44}$ Recently suggested improvement of ischemia technique involves early unclamping after initial parenchymal suture to reduce ischemia time. ${ }^{45}$ Generally, but especially in patients with a solitary kidney or other imperative indications for PN, the surgery should be per- formed without ischemia whenever technically feasible due to better postoperative glomerular filtration rate, lower likelihood of acute renal failure, and lower rates of new onset or worsening CKD. ${ }^{46}$

In recent years, centers of excellence have improved surgical techniques, and laparoscopic (LPN) as well as robotic-assisted (RAPN) techniques have been adopted for PN with equivalent short-term oncological results in experienced hands. ${ }^{47,48}$ Complication rates, including urine leaks, blood loss, and others have been decreased to an equal level for PN, LPN, and RAPN, whereas RAPN seems to be associated with less ischemia time compared with LPN. ${ }^{49-51}$

PN displays definitive advantages in functional outcomes with equal oncological outcomes for locally confined RCC and is gaining traction in clinical practice. Still, there is a general underuse of PN because PN is a demanding and technically challenging procedure and surgeons as well as patients seem to favor LRN over any kind of PN in certain settings. There is a higher chance of undergoing PN in teaching or tertiary care centers. $^{52}$

\section{Surgical Management of RCC with Venous Tumor Thrombus}

Uniquely, RCC demonstrates a frequent pattern of intraluminal growth into venous structures. This can involve the renal vein or the IVC and can progress as far as the right atrium.

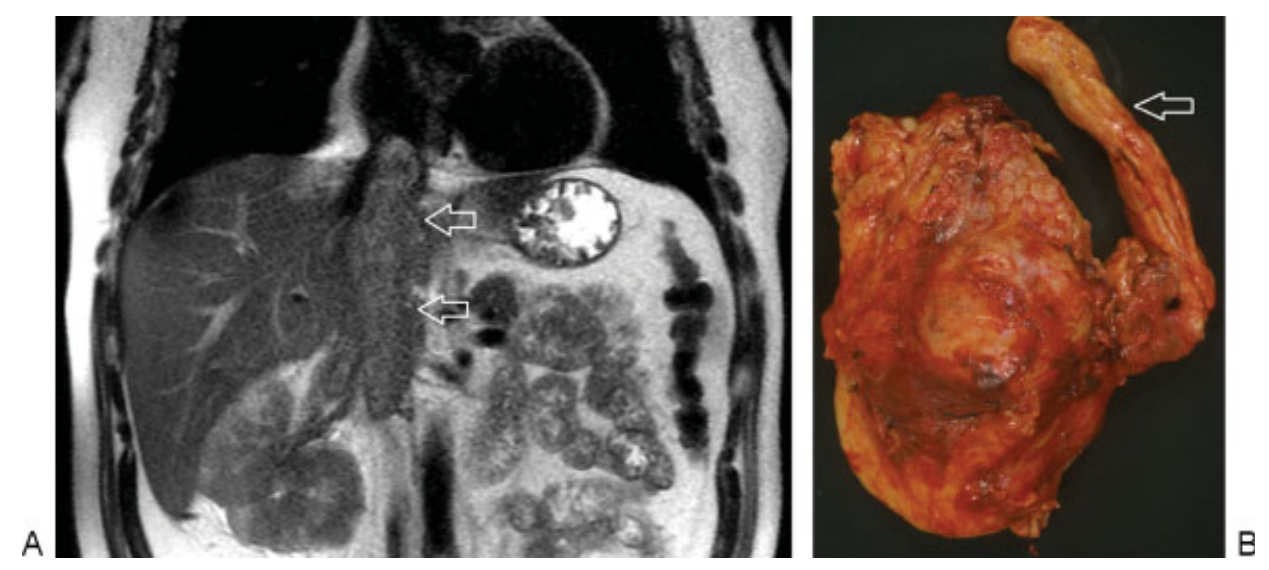

Figure 2 (A) Radiologic image of a tumor thrombus (arrows) and (B) a specimen including an inferior vena cava thrombus (arrow). 
Surgically, this represents a complex challenge, increasing with the level of tumor thrombus (confined to the renal vein, infradiaphragmatic IVC, and supradiaphragmatic IVC). IVC thrombus is present in 4 to $10 \%$ of cases of $\operatorname{RCC}^{53}$; therefore, preoperative imaging to detect and assess the exact extent of tumor thrombus is essential (see - Fig. 2). To date, MRI is the preferred diagnostic modality at many centers to demonstrate the presence and degree of venous involvement, with equal performance to a multidetector $\mathrm{CT}^{54} \mathrm{RN}$ in the presence of a renal vein thrombus is not significantly different from the typical procedure; however, IVC thrombi change the pattern of RN drastically. This includes mobilization of the liver and control of the supra- and infrarenal IVC, the contralateral renal vein, lumbar veins, porta hepatis, and other tributary veins for subdiaphragmatic thrombi. In cases with thrombus extension above the diaphragm, venovenous bypass or cardiopulmonary bypass with or without deep hypothermic circulatory arrest are required, and thereby necessitate a multidisciplinary approach. Usually, thrombi of RCC are not adherent to the venous wall and can be mobilized; when wall invasion into the IVC occurs, aggressive management is required with the necessity of venous wall reconstruction or replacement. ${ }^{55} \mathrm{RN}$ with tumor thrombectomy is associated with a high morbidity and mortality, with perioperative mortality rates of 2 to $4 \%$, early complication rates of $15 \%$ and late complication rates of up to $25 \%$. These potential complications make appropriate patient selection vital. $^{56,57}$ However, surgical extirpation of the kidney and tumor thrombus provides the only long-term cure possible in these patients, with 5-year OS rates between 40 and $65 \%$ in patients without metastasis and poorer survival of 5 to $25 \%$ in patients with metastases. ${ }^{58-60}$

\section{Cytoreductive Nephrectomy}

Cytoreductive nephrectomy $(\mathrm{CN})$ is used in patients with RCC who initially present in a metastatic RCC(mRCC) setting. Two prospective randomized trials demonstrated superior progression-free survival and OS in patients undergoing $\mathrm{CN}$ followed by immunotherapy compared with immunotherapy alone. ${ }^{61,62}$ In a combined analysis, patients treated with $\mathrm{CN}$ and immunotherapy had a survival benefit of 13.6 versus 7.8 months in patients undergoing immunotherapy alone. ${ }^{63}$ This is the reason that $\mathrm{CN}$ for patients with $\mathrm{mRCC}$ has been widely adopted, although only patients with good overall performance status were included and some poor prognostic metastatic sites (brain) were excluded, introducing a selection bias. $\mathrm{CN}$ is significantly more complicated than standard $\mathrm{RN}$, with in-hospital mortality rates of $5 \%$, indicating the need for careful patient selection. ${ }^{64}$

In the era of targeted therapies, the benefit of $\mathrm{CN}$ has been questioned again. To date, there are no prospective randomized controlled trials to answer this question, and other evidence is limited. Recent retrospective series suggest better outcomes for patients treated with $\mathrm{CN}$ before targeted therapy compared with targeted therapy alone, but again selection bias in these series limits conclusions. ${ }^{65,66}$ Two prospective randomized controlled trials are underway to provide Level-1 evidence regarding this matter.

\section{Metastasectomy in Patients with mRCC}

It should be reiterated that complete surgical resection is the only chance for cure in patients with RCC, including patients with mRCC, even though cures are uncommon in this latter group. Metastasis site has a significant impact on survival after metastasectomy, favoring lung and adrenal metastasis with 5-year OS rates of around 40 and $60 \%$ for single site metastasis, respectively, compared with bone and liver metastases (5-year OS rates around 15\%). ${ }^{67,68}$ The single most important factor for long-term success in case of single or even multiple metastasectomies is complete resection. ${ }^{69}$ Patients with complete resection of lung-only metastasis have a 5-year cancer-specific survival (CSS) rate of $73 \%$ compared with $19 \%$ without complete resection. In patients with nonlung-only metastasis, the difference in survival is also significant with a 5-year CSS rate of 33\% with complete resection and only $12 \%$ without. In the era of targeted agents there is still limited evidence, but it seems as if the abovementioned results can be transferred to the patient
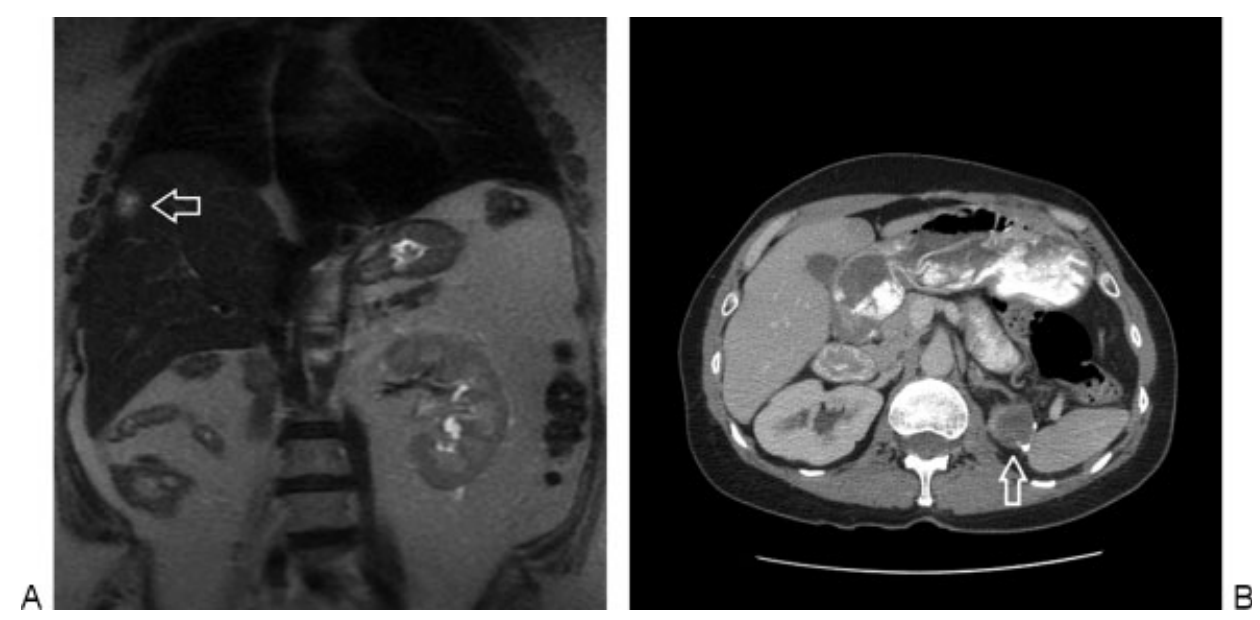

Figure 3 (A) Radiologic image of a resectable systemic metastasis (arrow) and (B) radiologic image of a resectable local recurrence (arrow). 
population undergoing targeted therapy as well, and emphasize the important role of multimodal and multidisciplinary approaches in mRCC (see - Fig. 3A). ${ }^{70}$

The same benefit as resection of a systemic metastasis is suggested to be true for isolated local recurrence of RCC. Likewise, aggressive and complete surgical resection can provide durable local tumor control, and a multimodal approach with thoughtful integration of systemic therapy should be considered in these patients (see - Fig. 3B). ${ }^{71}$ However, these patients face a significant risk of developing systemic disease, despite aggressive surgery and the need to be monitored closely.

In conclusion, surgical resection represents the standard of care for managing patients with renal masses. Radical nephrectomy is the gold standard for larger renal masses, whereas nephron-sparing PN is the preferred treatment modality for T1a tumors. The role of $\mathrm{CN}$ and metastasectomy/extirpation of local recurrence in advanced RCC is yet to be defined in the era of targeted therapies, but to date does represent the only opportunity for cure.

\section{References}

1 Siegel R, Naishadham D, Jemal A. Cancer statistics, 2013. CA Cancer J Clin 2013;63(1):11-30

2 Gill IS, Aron M, Gervais DA, Jewett MA. Clinical practice. Small renal mass. N Engl J Med 2010;362(7):624-634

3 Cohen HT, McGovern FJ. Renal-cell carcinoma. N Engl J Med 2005; 353(23):2477-2490

4 Volpe A, Panzarella T, Rendon RA, Haider MA, Kondylis FI, Jewett MA. The natural history of incidentally detected small renal masses. Cancer 2004;100(4):738-745

5 Gupta K, Miller JD, Li JZ, Russell MW, Charbonneau C. Epidemiologic and socioeconomic burden of metastatic renal cell carcinoma (mRCC): a literature review. Cancer Treat Rev 2008;34(3):193-205

6 Lam JS, Shvarts O, Leppert JT, Figlin RA, Belldegrun AS. Renal cell carcinoma 2005: new frontiers in staging, prognostication and targeted molecular therapy. J Urol 2005;173(6):1853-1862

7 Escudier B. Emerging immunotherapies for renal cell carcinoma. Ann Oncol 2012;23(Suppl 8):viii35-40

8 Robson CJ, Churchill BM, Anderson W. The results of radical nephrectomy for renal cell carcinoma. J Urol 1969;101(3): 297-301

9 Chow WH, Devesa SS, Warren JL, Fraumeni JF Jr. Rising incidence of renal cell cancer in the United States. JAMA 1999;281(17): 1628-1631

10 Kerbl K, Clayman RV, Mc Dougall E, Kavoussi LR. Laparoscopic nephrectomy: current status. Arch Esp Urol 1993;46(7): 581-584

11 Becker F, Siemer S, Humke U, Hack M, Ziegler M, Stöckle M. Elective nephron sparing surgery should become standard treatment for small unilateral renal cell carcinoma: long-term survival data of 216 patients. Eur Urol 2006;49(2):308-313

12 Sagalowsky AI, Kadesky KT, Ewalt DM, Kennedy TJ. Factors influencing adrenal metastasis in renal cell carcinoma. J Urol 1994; 151(5):1181-1184

13 Sandock DS, Seftel AD, Resnick MI. Adrenal metastases from renal cell carcinoma: role of ipsilateral adrenalectomy and definition of stage. Urology 1997;49(1):28-31

14 Tsui KH, Shvarts O, Barbaric Z, Figlin R, de Kernion JB, Belldegrun A. Is adrenalectomy a necessary component of radical nephrectomy? UCLA experience with 511 radical nephrectomies. J Urol 2000; 163(2):437-441
15 Blom JH, van Poppel H, Maréchal JM, et al; EORTC Genitourinary Tract Cancer Group. Radical nephrectomy with and without lymph-node dissection: final results of European Organization for Research and Treatment of Cancer (EORTC) randomized phase 3 trial 30881. Eur Urol 2009;55(1):28-34

16 Schafhauser W, Ebert A, Brod J, Petsch S, Schrott KM. Lymph node involvement in renal cell carcinoma and survival chance by systematic lymphadenectomy. Anticancer Res 1999;19(2C):1573-1578

17 Capitanio U, Jeldres C, Patard JJ, et al. Stage-specific effect of nodal metastases on survival in patients with non-metastatic renal cell carcinoma. BJU Int 2009;103(1):33-37

18 Giuliani L, Giberti C, Martorana G, Rovida S. Radical extensive surgery for renal cell carcinoma: long-term results and prognostic factors. J Urol 1990;143(3):468-473, discussion 473-474

19 Saitoh H, Nakayama M, Nakamura K, Satoh T. Distant metastasis of renal adenocarcinoma in nephrectomized cases. J Urol 1982; 127(6):1092-1095

20 Kerbl K, Clayman RV, McDougall EM, Kavoussi LR. Laparoscopic nephrectomy. BMJ 1993;307(6917):1488-1489

21 Gill IS, Meraney AM, Schweizer DK, et al. Laparoscopic radical nephrectomy in 100 patients: a single center experience from the United States. Cancer 2001;92(7):1843-1855

22 Chan DY, Cadeddu JA, Jarrett TW, Marshall FF, Kavoussi LR. Laparoscopic radical nephrectomy: cancer control for renal cell carcinoma. J Urol 2001;166(6):2095-2099, discussion 2099-2100

23 Wille AH, Roigas J, Deger S, Tüllmann M, Türk I, Loening SA. Laparoscopic radical nephrectomy: techniques, results and oncological outcome in 125 consecutive cases. Eur Urol 2004;45(4): 483-488, discussion 488-489

24 Hemal AK, Kumar A, Gupta NP, Kumar R. Oncologic outcome of 132 cases of laparoscopic radical nephrectomy with intact specimen removal for T1-2N0M0 renal cell carcinoma. World J Urol 2007; 25(6):619-626

25 Dunn MD, Portis AJ, Shalhav AL, et al. Laparoscopic versus open radical nephrectomy: a 9-year experience. J Urol 2000;164(4): 1153-1159

26 McDougall E, Clayman RV, Elashry OM. Laparoscopic radical nephrectomy for renal tumor: the Washington University experience. J Urol 1996;155(4):1180-1185

27 Huang WC, Elkin EB, Levey AS, Jang TL, Russo P. Partial nephrectomy versus radical nephrectomy in patients with small renal tumors-is there a difference in mortality and cardiovascular outcomes? J Urol 2009;181(1):55-61, discussion 61-62

28 Huang WC, Levey AS, Serio AM, et al. Chronic kidney disease after nephrectomy in patients with renal cortical tumours: a retrospective cohort study. Lancet Oncol 2006;7(9):735-740

29 Go AS, Chertow GM, Fan D, McCulloch CE, Hsu CY. Chronic kidney disease and the risks of death, cardiovascular events, and hospitalization. N Engl J Med 2004;351(13):1296-1305

30 Campbell SC, Novick AC, Belldegrun A, et al; Practice Guidelines Committee of the American Urological Association. Guideline for management of the clinical T1 renal mass. J Urol 2009;182(4): 1271-1279

31 Van Poppel H, Da Pozzo L, Albrecht W, et al. A prospective, randomised EORTC intergroup phase 3 study comparing the oncologic outcome of elective nephron-sparing surgery and radical nephrectomy for low-stage renal cell carcinoma. Eur Urol 2011; 59(4):543-552

32 Novick AC. Renal-sparing surgery for renal cell carcinoma. Urol Clin North Am 1993;20(2):277-282

33 Hafez KS, Fergany AF, Novick AC. Nephron sparing surgery for localized renal cell carcinoma: impact of tumor size on patient survival, tumor recurrence and TNM staging. J Urol 1999;162(6): 1930-1933

34 Lee CT, Katz J, Shi W, Thaler HT, Reuter VE, Russo P. Surgical management of renal tumors $4 \mathrm{~cm}$. or less in a contemporary cohort. J Urol 2000;163(3):730-736 
35 Crépel M, Jeldres C, Sun M, et al. A population-based comparison of cancer-control rates between radical and partial nephrectomy for T1A renal cell carcinoma. Urology 2010;76(4):883-888

36 Leibovich BC, Blute M, Cheville JC, Lohse CM, Weaver AL, Zincke H. Nephron sparing surgery for appropriately selected renal cell carcinoma between 4 and $7 \mathrm{~cm}$ results in outcome similar to radical nephrectomy. J Urol 2004;171(3):1066-1070

37 Patard JJ, Shvarts O, Lam JS, et al. Safety and efficacy of partial nephrectomy for all T1 tumors based on an international multicenter experience. J Urol 2004;171(6 Pt 1):2181-2185, quiz 2435

38 Margulis V, Tamboli P, Jacobsohn KM, Swanson DA, Wood CG. Oncological efficacy and safety of nephron-sparing surgery for selected patients with locally advanced renal cell carcinoma. BJU Int 2007;100(6):1235-1239

39 Castilla EA, Liou LS, Abrahams NA, et al. Prognostic importance of resection margin width after nephron-sparing surgery for renal cell carcinoma. Urology 2002;60(6):993-997

40 Sutherland SE, Resnick MI, Maclennan GT, Goldman HB. Does the size of the surgical margin in partial nephrectomy for renal cell cancer really matter? J Urol 2002;167(1):61-64

41 Marszalek M, Carini M, Chlosta P, et al. Positive surgical margins after nephron-sparing surgery. Eur Urol 2012;61(4):757-763

42 Lesage K, Joniau S, Fransis K, Van Poppel H. Comparison between open partial and radical nephrectomy for renal tumours: perioperative outcome and health-related quality of life. Eur Urol 2007; 51(3):614-620

43 Thompson RH, Lane BR, Lohse CM, et al. Renal function after partial nephrectomy: effect of warm ischemia relative to quantity and quality of preserved kidney. Urology 2012;79(2):356-360

44 Becker F, Van Poppel H, Hakenberg OW, et al. Assessing the impact of ischaemia time during partial nephrectomy. Eur Urol 2009; 56(4):625-634

45 Nguyen MM, Gill IS. Halving ischemia time during laparoscopic partial nephrectomy. J Urol 2008;179(2):627-632, discussion 632

46 Thompson RH, Lane BR, Lohse CM, et al. Comparison of warm ischemia versus no ischemia during partial nephrectomy on a solitary kidney. Eur Urol 2010;58(3):331-336

47 Permpongkosol S, Bagga HS, Romero FR, Sroka M, Jarrett TW, Kavoussi LR. Laparoscopic versus open partial nephrectomy for the treatment of pathological T1N0M0 renal cell carcinoma: a 5-year survival rate. J Urol 2006;176(5):1984-1988, discussion 19881989

48 Kyllo RL, Tanagho YS, Kaouk JH, et al. Prospective multi-center study of oncologic outcomes of robot-assisted partial nephrectomy for pT1 renal cell carcinoma. BMC Urol 2012;12:11

49 Lucas SM, Mellon MJ, Erntsberger L, Sundaram CP. A comparison of robotic, laparoscopic and open partial nephrectomy. JSLS 2012; 16(4):581-587

50 Froghi S, Ahmed K, Khan MS, Dasgupta P, Challacombe B. Evaluation of robotic and laparoscopic partial nephrectomy for small renal tumours (T1a). BJU Int 2013;112(4):E322-E333

51 Aboumarzouk OM, Stein RJ, Eyraud R, et al. Robotic versus laparoscopic partial nephrectomy: a systematic review and meta-analysis. Eur Urol 2012;62(6):1023-1033

52 Miller DC, Daignault S, Wolf JS Jr, et al. Hospital characteristics and use of innovative surgical therapies among patients with kidney cancer. Med Care 2008;46(4):372-379

53 Lawindy SM, Kurian T, Kim T, et al. Important surgical considerations in the management of renal cell carcinoma (RCC) with inferior vena cava (IVC) tumour thrombus. BJU Int 2012;110(7): 926-939

54 Capitanio U, Shariat SF, Isbarn H, et al. Comparison of oncologic outcomes for open and laparoscopic nephroureterectomy: a multi-institutional analysis of 1249 cases. Eur Urol 2009;56(1): $1-9$

55 Kwon TW, Kim H, Moon KM, et al. Surgical treatment of inferior vena cava tumor thrombus in patients with renal cell carcinoma. J Korean Med Sci 2010;25(1):104-109

56 Gettman MT, Boelter CW, Cheville JC, Zincke H, Bryant SC, Blute ML. Charlson co-morbidity index as a predictor of outcome after surgery for renal cell carcinoma with renal vein, vena cava or right atrium extension. J Urol 2003;169(4):1282-1286

57 Blute ML, Leibovich BC, Lohse CM, Cheville JC, Zincke H. The Mayo Clinic experience with surgical management, complications and outcome for patients with renal cell carcinoma and venous tumour thrombus. BJU Int 2004;94(1):33-41

58 Haferkamp A, Bastian PJ, Jakobi H, et al. Renal cell carcinoma with tumor thrombus extension into the vena cava: prospective longterm followup. J Urol 2007;177(5):1703-1708

59 Klatte T, Pantuck AJ, Riggs SB, et al. Prognostic factors for renal cell carcinoma with tumor thrombus extension. J Urol 2007;178(4 Pt 1):1189-1195, discussion 1195

60 Sweeney P, Wood CG, Pisters LL, et al. Surgical management of renal cell carcinoma associated with complex inferior vena caval thrombi. Urol Oncol 2003;21(5):327-333

61 Mickisch GH, Garin A, van Poppel H, de Prijck L, Sylvester R; European Organisation for Research and Treatment of Cancer (EORTC) Genitourinary Group. Radical nephrectomy plus interferon-alfa-based immunotherapy compared with interferon alfa alone in metastatic renal-cell carcinoma: a randomised trial. Lancet 2001;358(9286):966-970

62 Flanigan RC, Salmon SE, Blumenstein BA, et al. Nephrectomy followed by interferon alfa-2b compared with interferon alfa-2b alone for metastatic renal-cell cancer. N Engl J Med 2001;345(23): 1655-1659

63 Flanigan RC, Mickisch G, Sylvester R, Tangen C, Van Poppel H, Crawford ED. Cytoreductive nephrectomy in patients with metastatic renal cancer: a combined analysis. J Urol 2004;171(3): 1071-1076

64 Trinh QD, Bianchi M, Hansen J, et al. In-hospital mortality and failure to rescue after cytoreductive nephrectomy. Eur Urol 2012 (Sep):7

65 Bigot P, Lebdai S, Ravaud A, et al. The role of surgery for metastatic renal cell carcinoma in the era of targeted therapies. World J Urol 2013(Mar):30

66 Choueiri TK, Xie W, Kollmannsberger C, et al. The impact of cytoreductive nephrectomy on survival of patients with metastatic renal cell carcinoma receiving vascular endothelial growth factor targeted therapy. J Urol 2011;185(1):60-66

67 Kierney PC, van Heerden JA, Segura JW, Weaver AL. Surgeon's role in the management of solitary renal cell carcinoma metastases occurring subsequent to initial curative nephrectomy: an institutional review. Ann Surg Oncol 1994;1(4):345-352

68 Siemer S, Lehmann J, Kamradt J, et al. Adrenal metastases in 1635 patients with renal cell carcinoma: outcome and indication for adrenalectomy. J Urol 2004;171(6 Pt 1):2155-2159, discussion 2159

69 Alt AL, Boorjian SA, Lohse CM, Costello BA, Leibovich BC, Blute ML. Survival after complete surgical resection of multiple metastases from renal cell carcinoma. Cancer 2011;117(13):2873-2882

70 Tosco L, Van Poppel H, Frea B, Gregoraci G, Joniau S. Survival and impact of clinical prognostic factors in surgically treated metastatic renal cell carcinoma. Eur Urol 2013;63(4):646-652

71 Margulis V, McDonald M, Tamboli P, Swanson DA, Wood CG. Predictors of oncological outcome after resection of locally recurrent renal cell carcinoma. J Urol 2009;181(5):2044-2051 